\title{
In Vitro Anticancer and Cytotoxic Activities of Some Plant Extracts on HeLa and Vero Cell Lines ${ }^{\dagger}$
}

\author{
Fulya Tugba Artun 1, Ali Karagoz 2,*, Gul Ozcan 3, Gulay Melikoglu 4, Sezin Anil 4, \\ Sukran Kultur ${ }^{5}$ and Nurhayat Sutlupinar ${ }^{4}$ \\ 1 Institute of Science, Istanbul University, Istanbul 34452, Turkey \\ 2 Department of Molecular Biology and Genetics, Faculty of Science, Istanbul University, \\ Istanbul 34452, Turkey \\ 3 Department of Biology, Faculty of Science, Istanbul University, Istanbul 34452, Turkey \\ 4 Department of Pharmacognosy, Faculty of Pharmacy, Istanbul University, Istanbul 34452, Turkey \\ 5 Department of Pharmaceutical Botany, Faculty of Pharmacy, Istanbul University, Istanbul 34452, Turkey \\ * Correspondence: sanicula@istanbul.edu.tr; Tel.: +90-212-455-57-00 (ext. 15116); Fax: +90-212-514-03-66 \\ + Presented at the 2nd International Conference on Natural Products for Cancer Prevention and Therapy, \\ Kayseri, Turkey, 8-11 November 2017.
}

Published: 15 November 2017

\begin{abstract}
The aim of our study was to evaluate the effect of in vitro anticancer and cytotoxic activity of the methanolic extracts of 14 medicinal plants, 8 of which are endemic species in Anatolia, against the human HeLa cervical cancer cell line and to compare to the normal African green monkey kidney epithelial cell line (Vero) using the MTT colorimetric assay. Values for cytotoxicity measured by MTT assay were expressed as the concentration that causes $50 \%$ decrease in cell viability (IC ${ }_{50}$, $\mu \mathrm{g} / \mathrm{mL}$ ). The degree of selectivity of the compounds can be expressed by its selectivity index (SI) value. High SI value $(>2)$ of a compound gives the selective toxicity against cancer cells $\left(\mathrm{SI}=\mathrm{IC}_{50}\right.$ normal cell//I 50 cancer cell). Dose-dependent studies revealed IC 50 of $293 \mathrm{mg} / \mathrm{mL}$ and $>1000 \mathrm{mg} / \mathrm{mL}$ for Cotinus coggygria Scop., IC 50 of $265 \mu \mathrm{g} / \mathrm{mL}$ and $>1000 \mathrm{mg} / \mathrm{mL}$ for Rosa damascena Miller, IC 50 of 2 $\mu \mathrm{g} / \mathrm{mL}$ and $454 \mathrm{mg} / \mathrm{mL}$ for Colchicum sanguicolle K.M. Perss, IC 50 of $427 \mu \mathrm{g} / \mathrm{mL}$ and $>1000 \mu \mathrm{g} / \mathrm{mL}$ for Centaurea antiochia Boiss. var. praealta (Boiss \& Bal) Wagenitz on the HeLa cells and the Vero cells, respectively. Four plants showed significant SI values which were 227 for Colchicum sanguicolle K.M. Perss (endemic species), >3.8 for Rosa damascena Miller, $>3.4$ for Cotinus coggygria Scop. and >2.3 for Centaurea antiochia Boiss. var. praealta (Boiss \& Bal) Wagenitz (endemic species). According to our study, 4 methanolic extracts of 14 tested plants exhibit greater activity on the HeLa cell line and little activity on the Vero cell line, meaning that these plants can be evaluated for potential promising anticancer activity.
\end{abstract}

Keywords: anticancer activity; crude extracts; HeLa and Vero cell lines

(C) 2017 by the authors. Licensee MDPI, Basel, Switzerland. This article is an open access article distributed under the terms and conditions of the Creative Commons Attribution (CC BY) license (http://creativecommons.org/licenses/by/4.0/). 